\title{
Analysis of the Content and Path of Ideological and Political Education for College Students from the Perspective of Ecological Civilization
}

\author{
Lei Wang \\ School of Foreign Languages \\ Wuhan University of Technology \\ Wuhan, P.R. China
}

\begin{abstract}
In the overall layout of China's modernization construction, the construction of ecological civilization has been placed in a prominent position. This puts forward higher requirements for ideological and political education in colleges and universities. It is necessary to introduce ecological civilization ideological theory into ideological and political education in colleges and universities. Ecological outlook education, ecological responsibility education, and ecological ethics education are the contents of ideological and political education that enhance the concept of ecological civilization among college students. Improving college students' ecological cognition, enriching college students' ecological emotions, strengthening college students' ecological will, and improving college students' ecological practice are the paths of ideological and political education for college students that are consistent with the concept of ecological civilization.
\end{abstract}

Keywords-ecological civilization; college students; ideological and political education

\section{INTRODUCTION}

The construction of ecological civilization is a long-term plan that concerns the well-being of the people and the future of the nation. Colleges and universities shoulder the responsibility of cultivating social talents with a sense of ecological civilization. Introducing the theory of ecological civilization into the ideological and political education in colleges and universities is not only the need for the construction of ecological civilization in China, but also the need for ideological and political education in colleges and universities to advance with the times and to achieve sustainable development.

\section{INTRODUCING THE THEORY OF ECOLOGICAL} CIVILIZATION INTO THE CONTENT OF IDEOLOGICAL AND POLITICAL EDUCATION FOR COLLEGE STUDENTS

Ecological civilization education should permeate the entire educational content in the view that "human and nature should coexist harmoniously" in the Marxist ecological view. Through the enhancement of ecological and natural education, eco-responsibility awareness education and ecological ethics education in the content of college students' ideological and political education, the contents of ecological civilization education will be improved, and students will be able to form an ecological awareness of the harmonious coexistence between man and nature, and will also be ecological civilization. Theoretical knowledge translates into ways to understand nature and protect the ecological environment.

\section{A. Ecological Nature Education}

In the concept of ideological and political education, the problem of resolving the relationship between people and people and between people and society is generally regarded as the focus, while the relationship between man and nature is ignorant. With the continuous development and progress of human society, it is urgent to strengthen the education of ecological nature.

The theoretical source of the ecological view of nature is the Marxist dialectical relationship between man and nature. The concept of ecological nature believes that all biological and non-biological relationships in the natural world are interdependent and interrelated and inseparably organically unified. We should respect nature, conform to nature, and protect nature. If humans destroy the natural ecosystem and violate the objective laws, they should be punished. Human beings and nature are closely related, and human beings are closely dependent on nature. When human beings continue to ask for nature without fear and do not pay back, they will naturally be punished by nature.

The ecological nature outlook education is a new task that the university has given to the ideological and political education of college students, and it is an extension of the contents of ideological and political education. We must guide students to correctly understand the relationship between man and nature, clarify that we have the rights and freedom to transform nature, and also have the responsibility to protect nature. We should respect the existence of all natural living beings and strive to realize the harmonious coexistence between man and nature, and make them coexist and develop together. Through ideological and political education, college students can form the ecological cognition of harmonious coexistence between man and nature. 


\section{B. Education of Ecological Responsibility Awareness}

In the construction of ecological civilization advocated in our country, each individual is the main body, and can enjoy the achievements of ecological civilization construction. As one of the main body of ecological construction, college students have the responsibility and obligation to protect ecological security. Ideological and political education is carried out to strengthen the ecological responsibility awareness of college students as the subject of ecological value, and promote the harmonious development of human and nature by their spontaneous behavior.

The first step of college students ecological responsibility awareness education is to build up their confidence to change the ecology situation, and improve the environment. Secondly, the cultivation for students' responsibility awareness should be strengthened to make it clear that college students can realize their ecological rights and interests only if they regard ecological problems as their own problems. College students are in the mature stage of their natural and social attributes, and in the crucial period of forming scientific world outlook, outlook on life, and values, during which time their ideological thinking and behavior have strong plasticity. Therefore, as an important main force in the construction of ecological civilization, only when the college students are equipped with strong responsibility awareness of ecological development, and fully realize the ecological crisis and environmental degradation challenges faced by human beings, as well as form correct nature view, scientific development view to take the responsibility to protect environment spontaneously, can they become the creators and promoters of ecological civilization construction in our country.

\section{Ecological Moral Standard Education}

Ecology and morality are closely related to each other, and moral self-perfection is an important class for college students to learn. To strengthen the concept of ecological civilization in the ideological and political education of college students includes not only the education of ecological concept of nature and the education of ecological responsibility consciousness to harmonize the relationship between human and nature, but also the ecological moral standard education to guide students' actual behaviors. The main criterion of ecological moral education is whether or not it can promote the harmonious development of man and nature. It specifically points out what people should and should not do in the field of work life, public life, and family life, so as to guide people to form certain ecological moral behavior habits. The balance between man and nature and its sustainable development requires people to have the corresponding ecological moral level. When performing ecological moral standards, college students need to internalize the environmental consciousness of sustainable development into their own awakening consciousness, and then externalize it as sustainable behaviors such as environment protection, energy saving, reasonable consumption, and so on. In ideological and political education, to strengthen ecological moral standard education can makes college students familiar with the requirements of ecological moral standards, which can play an important role in guiding and binding the practical activities of college students and influencing their values, thus promoting them to become the main force of ecological civilization construction.

\section{EXPLORATION FOR THE APPROACH OF IDEOLOGICAL AND POLITICAL INSTITUTION FOR UNDERGRADUATES THAT SUITS ECOLOGICAL CIVILIZATION}

Consistent with ecological civilization construction, the implementation of university students' ideological and political education is expected to design a certain specific education approach that conforms to the laws of physical and psychological development of college students, adapts to the educational environment of colleges and universities and embodies ecological civilization to realize the unity of knowing and doing. However, there are two significant psychological aspects of "emotion" and "thoughts" that need to be grasped from the "knowledge" to the "action". The four aspects, "knowledge, affection, thoughts, and action", are closely associated with ecological civilization education, presenting as the progressive development from the surface to the profundity, to achieve internalization in mind and externalization in action. Under the guidance of the cultivation of undergraduates with ecological values, college ideological and political education bends itself to promoting college students' cognition, enriching their emotions, strengthening their volition, and enhancing their practice from the perspective of ecology which is conducive to selfimprovement of undergraduates. Therefore, university students will become all-round talents with the values of ecological civilization.

\section{A. Promotion of College Students' Ecological Awareness}

Ecological cognition determines undergraduates' behavior. First of all, colleges and universities should play their significant role in classroom instruction, which is expected to become the key position for college students to promote their ecological cognition. Besides, ecological civilization instruction curriculum should be practically admitted into ideological and political theory courses in colleges and universities. Based on classroom education, the contents and forms of ecological civilization education can be continuously enriched, which will form a comprehensive education system on and off campus as well as in the class and after class to assist college students to truly grasp the theory of ecological civilization, Help college students to truly grasp the theory of ecological civilization, improve university students' understanding of the relationship between man and nature as well as establish the ecological concept of harmonious development between man and nature. Secondly, ecological courses with professional features will be set up. It is well-known that some characteristics of ecological civilization education are the interdisciplinary discipline and the integration of knowledge synthesis and ecological ethics. Thus, it requires that colleges and universities integrate ecological environmental protection, ecological ethics as well as environmental protection knowledge and skills into the students' majors according to professional characteristics respectively, by which ecological 
responsibility awareness and thoughts can be rooted in university students' professional learning process. Only when college students realize the status quo and significance of ecological civilization construction through diversified ways, can they become the salt of the earth in the fields of ecological life and production. Last but not least, colleges and universities can also actively create a favorable ecological and civilized campus environment through various activities such as community activities, publicity and promotion, as well as practices. What's more, propaganda is necessary to carry out campus activities of ecological and cultural construction, contributing to integrating ecological concepts and ethical requirements into cultural activities and regular behavior of undergraduates. Hence, it can enhance students' ecological awareness and ecological moral consciousness of love and respect of nature within social practice and campus culture.

\section{B. To Enrich the Ecological Emotion of Undergraduates}

Ecological emotion refers to a certain subjective experience caused by the harmony between human beings and nature as well as interaction with each other, which is outwardly expressed as a sense of awe of natural life, intimacy toward green vitality, a expectancy for nature, and a positive attitude toward nature, etc. Ecological civilization education is the unity of cognition and emotional education, whose ultimate aim is to guide students to establish proper ecological values and practice correct ecological behavior. Emotional instruction is not only an emotional experience but an advanced and complex psychological feeling acquired by social practice. Once it is formed, it is characterized by perdurability.

In the ideological and political education in colleges and universities, the system of ecological theory can be constructed from the dimensions of ecological ethics and ecological laws on the basis of theoretical classes of ideological and political education, and knowledge can be conveyed to deepen students' ecological cognition and strengthen their awareness of ecological rights and obligations. Relevant eco-experts and professors can be employed to give special lectures on ecology and environmental science so that students can understand the current status of the actual ecological environment in China, future development trends and major environmental issues. Besides, students can be guided to establish a correct ecological ethics, and encouraged to actively participate in protecting the ecological environment. It is possible to disseminate, publicize and discuss ecological civilization education through effective publicity positions such as student clubs and new media, such as propagating festival events such as the Earth Day, the Environment Day and the trees planting Day, and encouraging students to participate in environmental protection. Moreover, students' aesthetic tastes can be improved through creating a good ecological environment in campus. Appropriate campus ecological environment is conducive to the cultivation of students' aesthetic appeal, and mobilizes the enthusiasm and consciousness of college students to care for the environment. Cultivating college students' rich ecological emotions can touch the minds of college students and promote the qualitative transformation of their thoughts and actions, so as to provide impetus for college students' environmental protection behaviors.

\section{Strengthen Ecological Will and Enhance Ecological Practice}

The construction of ecological civilization stresses the need to satisfy the equal and harmonious development of people, nature and society. In the face of environmental problems, college students should shoulder the social responsibility of saving resources, controlling consumption, and protecting the environment. To fulfill this responsibility, it is necessary to strengthen the ecological will and enhance the ecological practice. Therefore, college students' ideological and political education activities should attach importance to the cultivation of students' ability of ecological will and ecological practice. On the basis of guiding the students to scientifically understand the harmonious unity of people and the natural world, the college students should promote the ecological moral consciousness in the ecological will and behavior of daily life. Among them, it consciously assumes its due ecological moral responsibility in daily practice activities. Ideological and political education in institutions of higher education launches educational activities to strengthen college students' will for action. First of all, students should be guided to establish correct ecological concepts through media campaigns, community calls, etc., including making full use of new media forms such as Weibo and Wechat to vigorously promote ecological environmental protection knowledge and cases, and create a positive and upbeat campus ecological cultural atmosphere. Students will conscientiously correct bad ecological behaviors in an ecological and cultural environment in such a harmonious campus. Secondly, it is necessary to actively build various platforms to organize and implement ecological activities for college students through various forms, such as organizing campaigns for saving food, water, electricity, low-carbon emission reduction, energy saving and environmental protection for science and technology innovation activities in campus. The college students will apply the knowledge and theory of ecological civilization they learned to practice, so as to enhance the sense of responsibility and mission of the university students to participate in the construction of ecological civilization, cultivate the good energy-saving living habits, and improve their practical ability in environmental protection. Finally, university students can be encouraged to serve as environmental volunteers, thus they can actively participate in environmental protection and environmental protection activities in terms of public welfare, and consciously accept the supervision and management of environmental protection, in order to enhance the persistence and consciousness of the university students' ecological will and behavior.

\section{CONCLUSION}

As a consequence, It is necessary to introduce ecological civilization ideological theory into ideological and political 
education in colleges and universities. Ecological outlook education, ecological responsibility education, and ecological ethics education are the contents of ideological and political education that enhance the concept of ecological civilization among college students. Improving college students' ecological cognition, enriching college students' ecological emotions, strengthening college students' ecological will, and improving college students' ecological practice are the paths of ideological and political education for college students that are consistent with the concept of ecological civilization.

\section{REFERENCES}

[1] Marx and Engels Collected Works (Volume 9) [M]. Beijing: People's Education Press, 2009.

[2] Marx and Engels Collected Works (Volume 2) [M]. Beijing: People's Education Press, 2009.

[3] The Important Speeches Made by Secretary General Xi Jinping (2016 Edition) [M]. Beijing: Learning Press, Chinese People's Publishing House, 2016

[4] Dong Qiang. Research on Marxist Ecological View [M]. Beijing: People's Publishing House, 2015.

[5] Liao Fulin. Theory and Practice of Ecological Civilization Construction [M]. Beijing: China Forestry Publishing House, 2003.

[6] Duan Weiwei, Jiao Jiacheng. Exploration of Contemporary College Students' Ecological Civilization Education [J].Jiangsu Higher Education, 2013(6).

[7] Qiu Youhua.Ecological Civilization Education for College Students from the Perspective of Ideological and Political Education [J].Theory of Ideological and Theoretical Education 2014(7). 